\title{
CDISC SEND Food and Water Consumption Test Code Terminology
}

National Cancer Institute

\section{Source}

National Cancer Institute. CDISC SEND Food and Water Consumption Test Code

Terminology. NCI Thesaurus. Code C89970.

The terminology that includes concepts relevant to the Clinical Data Interchange Standards Consortium (CDISC) Standard for the Exchange of Non-clinical Data (SEND) food and water consumption test short names. 